\title{
The influence of illness and calcium intake on rate of skeletal maturation in children
}

\author{
BY AUDREY CAHN AND A. F. ROCHE \\ Departments of Biochemistry and Anatomy, University of Melbourne \\ (Received 29 December 1960-Revised 6 March I96I)
}

It is well known that children of the same age, sex and race vary in skeletal maturity, although little is known of the relative importance of the factors that might be responsible. Skeletal retardation has been shown to be associated with adverse environment and nutritive failure (see, for example, Dreizen, Snodgrasse, Webb-Peploe \& Spies, 1957), but observations based upon such indefinite terms do not help to determine the causes of the observed variations. The present report concerns the possible correlations between skeletal maturation rates, illnesses and different calcium intakes in children who were examined serially. There is no evidence that these factors were correlated in these children.

\section{METHODS}

This investigation was based upon illness records, levels of Ca intake and assessments of skeletal maturation for I 20 normal Australian children studied between the ages of 2 and 7 years. The selection of the children, the general programme in which they are enrolled and the nature of the dietary records have been described elsewhere (Roche \& Sunderland, I959; Cahn \& Neal, I959). None of the children had, at any time, suffered from severe illnesses or those, e.g. hyper-parathyroidism, known to change markedly the metabolism of $\mathrm{Ca}$. At all ages, the heights and weights of the median boys and girls in this group were close to those reported for normal Australian children (McElwain, I949; Meyers, I956).

The illness records have been compiled from paediatric examinations and have been evaluated by the score system described by Valadian, Stuart \& Reed (I959). The assessments of skeletal age have been made on the left hand and wrist with the Greulich \& Pyle (1959) atlas as a standard. These examinations and assessments have been made at 3 -month intervals until the age of 4 years, after which they were made every 6 months.

The $\mathrm{Ca}$ intakes have been calculated from weekly food records and questionnaires taken at 6-month intervals. Such a method cannot yield an exact assessment of $\mathrm{Ca}$ intake, but it can indicate the approximate intake and abnormalities that may influence nutritional status. For the purpose of this study, it is considered that the degree of accuracy was sufficient to have made apparent the relations, if any, between illness, calcium intake and skeletal maturation.

For each child three graphs were drawn. One of these showed the divergence of the $\mathrm{Ca}$ intake of each child from the mean for the group at each age. Similarly, the other 
graphs showed the divergences for skeletal maturation and for illness score. These graphs provided an index of skeletal maturity and Ca intake at the time of the examinations and illness score between examinations. A central point was added to each graph which represented the mean of the ages at which assessments were made and the mean of the divergences from the group means at these ages. 'The trend line was drawn through this point at the same slope as a line connecting the midpoint between the first two points on the graph to the midpoint between the last two. 'This method of fitting trend lines was used for each characteristic studied and has been described fully by Gibson \& Jowett (I957). Values obtained from these trend lines were used in the statistical analyses.

A recommended intake cannot be used as a standard to judge the adequacy of a diet in respect of any nutrient. In this study, the $\mathrm{Ca}$ intake of each child was compared with the mean for all the children of the same sex at each assessment and not with the recommended intakes. The question of adequacy was not considered.

Some nutrients other than $\mathrm{Ca}$ are concerned in the growth of bone, notably vitamin $\mathrm{D}$, phosphate, protein and the co-factors involved in protein synthesis. All Australian children are much exposed to sunlight which, together with dietary sources, should ensure an adequate supply of vitamin $\mathrm{D}$. The mean intakes of all the other nutrients mentioned above have been shown to be at levels above the recommended intakes which incorporate margins of safety (Cahn \& Neal, 1959).

\section{RESULTS}

The frequency distribution of the trend-line values at the age of 4 years for each characteristic is recorded in Tables I-3. For some children, information was incomplete for one or more of the characteristics studied and trend-line values could not be obtained. Median values for illness score and median skeletal-maturation rates, calculated for children for whom information was complete, were very close to those reported for American children (Greulich \& Pyle, I959; Valadian et al. I959) and the

Table I. Frequency distribution of trend-line values (see p. $4 \mathrm{I} \mathrm{I}$ )

\begin{tabular}{|c|c|c|}
\hline Intervals & Boys & Girls \\
\hline-2 to $-I \cdot I$ & 8 & 12 \\
\hline$-I$ to $-0 \cdot I$ & 27 & I8 \\
\hline 0 to +0.9 & 8 & 19 \\
\hline$+I$ to $+I \cdot 9$ & 3 & 4 \\
\hline+2 to +2.9 & 2 & 5 \\
\hline+3 to +3.9 & $\mathbf{I}$ & 0 \\
\hline+4 to +4.9 & 2 & 0 \\
\hline+5 to $+5 \cdot 9$ & I & $\circ$ \\
\hline Total & 52 & $5^{8}$ \\
\hline Median & -0.34 & -0.06 \\
\hline
\end{tabular}

\footnotetext{
* The illness record for each child has been scored by the method of Valadian et al. (1959) and has been expressed in comparison with the mean for the same sex. The mean values were $I \cdot 3$ units (boys) and $\mathrm{I}_{4} 4$ units (girls). Positive values indicate high levels of illness, negative values indicate low levels.
} 
median daily Ca intakes of $\mathrm{I} \cdot 02 \mathrm{~g}$ (boys) and $0.97 \mathrm{~g}$ (girls) were respectively at and just below the Australian recommended intakes for this age group (Wilson, 1954; Cahn \& Neal, I959; Cahn \& Hepburn, 1960). The lowest Ca intake for any child at any assessment was $0.23 \mathrm{~g}$ daily.

In children who suffered from an unusually large amount of illness, there was a wide range of skeletal maturity, from advanced to retarded, and there was a similar wide range in those children who had suffered from a small amount of illness. There was no evidence to suggest that any particular illnesses had immediate or delayed effects on the rate of skeletal maturation.

Table 2. Frequency distribution of trend-line values (see p. $4 \mathrm{II}$ ) for level of calcium intake* at the age of 4 years

$\begin{array}{lrc}\text { Intervals }(\mathrm{g}) & \text { Boys } & \text { Girls } \\ -0.4 \text { to }-0.3 \mathrm{I} & \mathrm{I} & 3 \\ -0.3 \text { to }-0.2 \mathrm{I} & 2 & 4 \\ -0.2 \text { to }-0.1 \mathrm{I} & \mathrm{r} 3 & 6 \\ -0 . \mathrm{I} \text { to }-0.0 \mathrm{I} & \mathrm{IO} & 10 \\ 0.0 \text { to }+0.09 & \mathrm{I} 2 & \mathrm{I3} \\ +0 . \mathrm{I} \text { to }+0.19 & 8 & \mathrm{II} \\ +0.2 \text { to }+0.29 & 3 & 4 \\ +0.3 \text { to }+0.39 & 2 & 0 \\ +0.4 \text { to }+0.49 & 0 & 0 \\ +0.5 \text { to }+0.59 & \mathrm{I} & 0 \\ \text { Total } & 52 & 5 \mathrm{I} \\ \text { Median }(\mathrm{g}) & -0.0 \mathrm{I} & +0.02\end{array}$

* The Ca intake for each child has been expressed in comparison with the mean for the same sex. The mean intake, regarded as the standard, was $\mathrm{I} .02 \mathrm{~g}$ (boys) and $0.97 \mathrm{~g}$ (girls). Positive values indicate high $\mathrm{Ca}$ intake, negative values low.

Table 3. Frequency distribution of trend-line values (see p. $4 \mathrm{II})$ for skeletal maturity* levels at the age of 4 years

$\begin{array}{lrr}\text { Intervals (months) } & \text { Boys } & \text { Girls } \\ -15 \text { to }-10.1 & 3 & 1 \\ -10 \text { to }-5.1 & 5 & 9 \\ -5 \text { to }-0.1 & 20 & 10 \\ \text { o to }+4.9 & 15 & 22 \\ +5 \text { to }+9.9 & 5 & 6 \\ + \text { I to }+14.9 & 2 & 1 \\ + \text { I } 5 \text { to }+19.9 & 2 & 0 \\ \text { Total } & 52 & 49 \\ \text { Median (months) } & -0.5 & +1.0\end{array}$

* Skeletal maturity has been expressed in comparison with the mean for the same sex. The mean values were 46.8 months (boys) and 45.2 months (girls). Positive values indicate advanced rates, negative values retarded.

The correlation coefficient between the trend-line values for illness and skeletal maturity at the age of 4 years was not significant at the $5 \%$ level (Table 4 ). The correlations between trend-line values for illness at one age and skeletal maturity 
2 years later were not significant at the $5 \%$ level (Table 4 ). Scatter diagrams indicated that there was no consistent relationship between the direction of slope of the trend lines for skeletal maturity and illness.

Table 4. Summary of the results of the statistical calculations

\begin{tabular}{|c|c|c|c|}
\hline Variable & $\begin{array}{c}\text { Correlation } \\
\text { coefficient } \\
r\end{array}$ & $\begin{array}{l}\text { Degrees } \\
\quad \text { of } \\
\text { difference }\end{array}$ & $\begin{array}{c}\text { Critical } \\
\text { values for } \\
r \text { at } 5 \% \\
\text { level }\end{array}$ \\
\hline $\mathrm{Ca}$ intake at 4 years to skeletal maturation at 4 years & $\begin{array}{l}\text { Girls +0.16 } \\
\text { Boys +o.15 }\end{array}$ & $\begin{array}{l}48 \\
5 \mathrm{I}\end{array}$ & $\begin{array}{l}0.28 \\
0.27\end{array}$ \\
\hline $\mathrm{Ca}$ intake at 3 years to skeletal maturation at 5 years & $\begin{array}{l}\text { Girls +o.15 } \\
\text { Boys +o.20 }\end{array}$ & $\begin{array}{l}46 \\
5 I\end{array}$ & $\begin{array}{l}0.28 \\
0.27\end{array}$ \\
\hline Illness score at 4 years to skeletal maturation at 4 years & $\begin{array}{l}\text { Girls }-0.18 \\
\text { Boys }-0.16\end{array}$ & $\begin{array}{l}45 \\
48\end{array}$ & $\begin{array}{l}0.29 \\
0.28\end{array}$ \\
\hline Illness score at 3 years to skeletal maturation at 5 years & $\begin{array}{l}\text { Girls }-0.12 \\
\text { Boys }-0.13\end{array}$ & $\begin{array}{l}45 \\
48\end{array}$ & $\begin{array}{l}0.29 \\
0.28\end{array}$ \\
\hline
\end{tabular}

These correlation coefficients were not significant at the $5 \%$ level.

Children who missed examinations because they were sick increased in skeletal age just as regularly as those children who attended every examination. Lines of best fit were added to the skeletal age graphs of the children who had missed an examination and these lines were calculated separately for the points before the missed visit and for those after it. These lines were extended so that two separate calculations were made of the missed assessment. The observed differences in height and slope of the two lines and between the two calculated assessments were not statistically significant.

The dietary pattern and the $\mathrm{Ca}$ intake of each child were fairly consistent throughout the period of the study. Most irregularities in the pattern of an individual child were associated with illness or change in environment close to the time of an assessment. 'The $\mathrm{Ca}$ intakes of some children were consistently low compared with the means for the group, but the skeletal maturity of these children ranged from considerably advanced to equally retarded values and a similar range of skeletal maturity was found in children whose $\mathrm{Ca}$ intakes were consistently high.

The correlation coefficient between the $\mathrm{Ca}$ intake and skeletal maturity at the same age was not significant at the $5 \%$ level (Table 4 ). There was no evidence that a low $\mathrm{Ca}$ intake had a delayed effect on the rate of skeletal maturation (Table 4 ). Comparison of the slopes of the trend lines for the $\mathrm{Ca}$ intake and skeletal maturity by scatter diagrams gave no evidence to support an assertion that there was a significant correlation (at the $5 \%$ level) between a rising or falling trend in $\mathrm{Ca}$ intake and a rising or falling trend in skeletal maturity.

All the children, except four, were breast-fed from birth, but the duration of uncomplemented breast feeding varied from 2 weeks to 9 months and, with a few, some breast feeding was continued for $\mathrm{I} 4$ months. The duration of breast feeding, before cow's milk replaced breast milk as the main Ca source, bore no relationship to the level of skeletal maturity at the age of 3 or 5 years. 
The data available did not indicate that a combination of a high incidence of illness and a low $\mathrm{Ca}$ intake retarded skeletal maturation, nor did it appear that the opposite extremes of illness record and $\mathrm{Ca}$ intake resulted in its acceleration.

\section{DISCUSSION}

There is general agreement that the common illnesses of childhood are associated with retardation in skeletal growth, but not on the nature of this retardation. Different workers have reported equal retardation of all ossification centres (Francis, 1940; Pyle \& Sontag, I943); greater retardation of carpal than epiphyseal centres (Francis, I939; Buehl \& Pyle, 1942) and selective retardation of those centres about to ossify at the time of the illness (Francis, 1939; Francis, Werle \& Behm, I939; Greulich \& Pyle, 1959). Others have reported that delayed carpal ossification was not always associated with illness and that illnesses may be responsible for advanced epiphyseal ossification (Sontag \& Lipford, 1943).

The findings presented in this paper show that, in the children studied, the amount of illness had no apparent immediate or delayed effect on the rate of skeletal maturation. Although these findings are in conflict with those of most earlier investigators, they are in general agreement with those reported by Hewitt, Westropp \& Acheson (1955) and Falkner (1958). The observations reported here do not exclude the possibility that illnesses of greater severity than those observed in this group of children could retard skeletal maturation, as has been reported for some cases of illness with fatal termination (Park, 1954).

Many early studies of Ca balance have been criticized by Leitch \& Aitken (1959) because $\mathrm{Ca}$ intake was not assessed before the tests and the choice of level of intake for the tests was insufficiently considered. In addition, they pointed out that endogenous losses of $\mathrm{Ca}$ in children were wrongly assumed to be negligible and drew attention to the importance of the relationship between $\mathrm{Ca}$ retention and estimated skeletal increment. They stated that percentage retention was not a valid criterion for converting theoretical skeletal increment into required level of $\mathrm{Ca}$ intake. They concluded that, for most children of the age considered in this paper, the $\mathrm{Ca}$ intake which would allow the necessary skeletal increment was likely to be about $0.3^{6} \mathrm{~g} /$ day. It has been shown, however, that in some children aged $\mathrm{I}-6$ years, skeletal maturation proceeded at a normal rate when the combined calcium and phosphorus intake was $0.2-0.7 \mathrm{~g} /$ day and the vitamin D intake was less than 200 i.u./day (Allen, MacLeod \& Young, 1953).

As a result of the present study we conclude that $\mathrm{Ca}$ intake does not influence the rate of skeletal maturation within the range of $\mathrm{Ca}$ intake found in this group of Australian children. Many of the children were receiving less than the recommended intake of $\mathrm{Ca}$, but nevertheless they matured skeletally at average or accelerated rates, which confirms the findings of Allen et al. (1953). This result could be due to differences in the ability of these Australian children to retain and utilize Ca for skeletal increments or to the generous value of the recommended intake. Wide variations between children in the ability to retain Ca have been reported (Holmes, 1945) and hese variations may be related to skeletal maturation rates (Macy, 1942) and to Ca 
intake (Nicholls \& Nimalasuriya, I939; Hoff-Jørgensen, Andersen \& Nielsen, 1946; Allen et al. 1953).

Reports on the effects of breast and artificial feeding on skeletal maturation and Ca metabolism are contradictory. Francis (1940) reported that early weaning was not associated with an increased rate of skeletal maturation, but accelerated maturation was reported by Valquist, Mellander \& Wicklund (1957). Ca retention was shown to be higher in artificially fed infants than in those breast-fed (Shohl, 1939), although serum $\mathrm{Ca}$ levels have been reported to be lower in infants given concentrated mixtures made from cow's milk (American Academy of Pediatrics, Committee of Nutrition, 1957). Macy (1932) reported better utilization of $\mathrm{Ca}$ by breast-fed children than by those fed on cow's milk.

The contradictory nature of the opinions expressed in the literature concerning the effects of illness on Ca retention (Jeans \& Stearns, I933; Daniels, I94I; Stearns, 1953) may result from the failure of investigators to exclude the sources of inaccuracy described by Leitch \& Aitken (1959).

The methods of investigation used in our study have not revealed any evidence that common illnesses or different $\mathrm{Ca}$ intakes influence the rate of skeletal maturation. It would, however, be unwise to conclude that the rate of skeletal maturation would not be altered by illnesses of greater severity or by levels of $\mathrm{Ca}$ intake markedly lower than those recorded during this study.

\section{SUMMARY}

I. Data are presented on the incidence of illness, calcium intake and skeletal maturation in 120 normal Australian children examined serially from 2 to 7 years.

2. There was evidence that neither the amount of illness nor particular types of illness had any influence on the level of skeletal maturity or the rate of change in skeletal maturation.

3. The progress in skeletal maturation was as regular in children who missed examinations because of illness as in those who did not.

4. There was no indication that within the range of $\mathrm{Ca}$ intake of these children the $\mathrm{Ca}$ intake had any immediate or delayed effect on the rate of skeletal maturation.

5. These findings do not exclude the possibility that skeletal maturity might be influenced by illnesses of greater severity than those observed or by lower $\mathrm{Ca}$ intakes than those recorded.

This work was supported financially by the Nuffield Foundation and the National Health and Medical Research Council of Australia. We are grateful to Professor V. M. Trikojus (Biochemistry) and Associate Professor L. J. Ray (Anatomy) of this University for their encouragement and advice. Our thanks are due to Dr J. J. M. O'Neill, who made the paediatric examinations, to Dr G. H. Jowett of the Statistics Department for his assistance and to Mrs R. Hepburn and Mrs G. De Pury for their help with the dietary assessments. 


\section{REFERENCES}

Allen, T., MacLeod, A. V. \& Young, E. G. (1953). Canad. F. med. Sci. 3x, 447.

American Academy of Pediatrics, Committee of Nutrition. (1957). Pediatrics, Springfield, r9, 339.

Buehl, C. C. \& Pyle, S. I. (I942). F. Pediat. 21, 335.

Cahn, A. \& Hepburn, R. (1960). Med. F. Aust. ii, 333.

Cahn, A. \& Neal, K. (1959). Med. F. Aust. ii, 549.

Daniels, A. L. (r94r). Amer. F. Dis. Child. 62, 279.

Dreizen, S., Snodgrasse, R. M., Webb-Peploe, H. \& Spies, T. D. (r957). Amer. F. Roentgenol. 78, 461.

Falkner, F. (1958). Amer. F. phys. Anthrop., N.S., 16, 38 r.

Francis, C. C. (1939). Amer. F. Dis. Child. 57, 817.

Francis, C. C. (r 940). Amer. F. Dis. Child. 59, 1006.

Francis, C. C., Werle, P. P. \& Behm, A. (1939). Amer. F. phys. Anthrop. 24, 273.

Gibson, W. M. \& Jowett, G. H. (1957). Appl. Statist. 6, I I4.

Greulich, W. W. \& Pyle, S. I. (1959). Radiographic Atlas of Skeletal Maturation of the Hand and Wrist, and ed. Stanford: Stanford University Press.

Hewitt, D., Westropp, C. K. \& Acheson, R. M. (1955). Brit. F. prev. soc. Med. 9, I79.

Hoff-Jorgensen, E., Andersen, O. \& Nielsen, G. (1946). Biochem. F. 40, 555.

Holmes, J. O. (1945). Nutr. Abstr. Rev. 14, 597.

Jeans, P. C. \& Stearns, G. (1933). Amer. F. Dis. Child. 46, 69.

Leitch, I. \& Aitken, E. C. (I959). Nutr. Abstr. Rev. 29, 393.

Macy, I. G. (1932). Yale F. Biol. Med. 4, 45 I.

Macy, I. G. (1942). Nutrition and Chemical Growth in Childhood, Vol. r. Springfield, Ill.: Charles C. Thomas.

McElwain, D. W. (1949). The Establishment of Norms for Heights and Weights of Infant and Pre-school Children in the City of Melbourne. 1946. Melbourne: Melbourne City Council.

Meyers, E. S. A. (1956). Med. F. Aust. i, 435.

Nicholls, L. \& Nimalasuriya, A. (1939). F. Nutr. 18, 563.

Park, E. A. (1954). Arch. Dis. Childh. 29, 269.

Pyle, I. \& Sontag, L. W. (1943). Amer. F. Roentgenol. 49, 795.

Roche, A. F. \& Sunderland, S. (1959). Med. F. Aust. i, 559.

Shohl, A. T. (1939). Mineral Metabolism. New York: Reinhold Publishing Corp.

Sontag, L. W. \& Lipford, J. (1943). F. Pediat. 23, 391.

Stearns, G. (1953). In Metabolic Interrelations zoith Special Reference to Calcium, p. I 85. Transactions of the Fifth Conference. [E. C. Riefenstein, Jr., editor.] New York: Josiah Macy Jr. Foundation.

Valadian, I., Stuart, H. C. \& Reed, R. B. (1959). Pediatrics, Springfield, 24, 94I.

Valquist, B., Mellander, O. \& Wicklund, H. (1957). Ann. Paediat. Fenn. 3, 5 I 3.

Wilson, W. (1954). Med. F. Aust. ii, I13. 